D) Check for updates

Cite this as: BMJ 2021;373:n1624 http://dx.doi.org/10.1136/bmj.n1624

Published: 24 June 2021

\section{Lateral flow tests cannot rule out SARS-CoV-2 infection}

This editorial by John Deeks and Angela Raffle (BMJ 2020;371:m4787, doi:) wrongly stated that a company's staff were involved in NHS Test and Trace lateral flow testing. The online version has been amended. 